\title{
Modeling Hydroclimatic Change in Southwest Louisiana Rivers
}

\author{
Z. George Xue ${ }^{1,2,3, *}$, David J. Gochis ${ }^{4}$, Wei Yu ${ }^{4}$, Barry D. Keim ${ }^{5}$, Robert V. Rohli ${ }^{1}$, \\ Zhengchen Zang ${ }^{1}$, Kevin Sampson 4 (i), Aubrey Dugger ${ }^{4}$, David Sathiaraj ${ }^{5,6}$ and Qian Ge ${ }^{7}$ \\ 1 Department of Oceanography and Coastal Sciences, Louisiana State University, Baton Rouge, \\ LA 70803, USA; rohli@lsu.edu (R.V.R.); zzang1@lsu.edu (Z.Z.) \\ 2 Center for Computation and Technology, Louisiana State University, Baton Rouge, LA 70803, USA \\ 3 Coastal Studies Institute, Louisiana State University, Baton Rouge, LA 70803, USA \\ 4 National Center for Atmospheric Research, Research Applications Laboratory, Boulder, CO 80305, USA; \\ gochis@ucar.edu (D.J.G.); weiyu@ucar.edu (W.Y.); ksampson@ucar.edu (K.S.); adugger@ucar.edu (A.D.) \\ 5 Department of Geography \& Anthropology, Louisiana State University, Baton Rouge, LA 70803, USA; \\ keim@lsu.edu (B.D.K.); davids@srcc.lsu.edu (D.S.) \\ 6 NOAA Southern Regional Climate, Louisiana State University, Baton Rouge, LA 70803, USA \\ 7 Key Laboratory of Submarine Geoscience, Second Institute of Oceanography, State Oceanic Administration, \\ Hangzhou 320012, China; gq980447@hotmail.com \\ * Correspondence: zxue@lsu.edu; Tel.: +225-578-1118; Fax: +225-578-6513
}

Received: 29 March 2018; Accepted: 27 April 2018; Published: 4 May 2018

\begin{abstract}
We applied the newly developed WRF-Hydro model to investigate the hydroclimatic trend encompassing the three basins in Southwest Louisiana as well as their connection with large-scale atmospheric drivers. Using the North American Land Data Assimilation System Phase 2 (NLDAS-2), we performed a multi-decadal model hindcast covering the period of 1979-2014. After validating the model's performance against available observations, trend and wavelet analysis were applied on the time series of hydroclimatic variables from NLDAS-2 (temperature and precipitation) and model results (evapotranspiration, soil moisture, water surplus, and streamflow). Trend analysis of model-simulated monthly and annual time series indicates that the regional climate is warming and drying over the past decades, specifically during spring and summer (growing season). Wavelet analysis reveals that, since the late 1990s, the anomaly of evapotranspiration, soil moisture, and streamflow exhibits high coherency with that of precipitation. Pettitt's test detects a possible change-point around the year 2004, after which the monthly precipitation decreased from 140 to $120 \mathrm{~mm}$, evapotranspiration slightly increased from 80 to $83 \mathrm{~mm}$, and water surplus decreased from 60 to $38 \mathrm{~mm}$. Changes in regional climate conditions are closely correlated with large-scale climate dynamics such as the Atlantic Multidecadal Oscillation (AMO) and El Niño Southern Oscillation (ENSO).
\end{abstract}

Keywords: WRF-Hydro; coastal river; ENSO; AMO; NLDAS-2

\section{Introduction}

Climate changes are introducing significant disturbances to the water cycle within river basins globally [1]. The uncertainty of climate change impacts on coastal rivers (e.g., regional rivers discharging directly into the ocean) is exacerbated by high population density [2], rising sea level and subsidence [3], salt water intrusion [4]), and vulnerability to extreme climate events such as winter storms and tropical cyclones [5].

Trend analysis indicates that the southeastern United States experienced warming summers during the period of 1948-2012. While autumn became wetter, spring and summer are characterized by 
drying over that period [6]. For the Gulf of Mexico coast, the hydroclimatic trend over the same period is characterized by an increasing temperature since the 1970s and a general increasing precipitation and streamflow over the last century $[7,8]$.

On a shorter timescale, intra-annual changes in regional temperature and precipitation are usually coupled with hemispheric-scale climate dynamics such as the North Atlantic Oscillation (NAO), Atlantic Multi-decadal Oscillation (AMO), El Niño-Southern Oscillation (ENSO), and Pacific Decadal Oscillation (PDO) (e.g., [9-11]). For instance, significantly lower river flows of the Pascagoula River in Mississippi could be expected during the coupling between the AMO warm and ENSO cold phases [12]. For the future, ensembles of Intergovernmental Panel on Climate Change (IPCC) global models project a decrease in precipitation, which, combined with the increasing temperature, will likely result in a decrease in runoff in the study area $[8,13]$.

In this study, we focus on three coastal river basins in Southwest Louisiana, United States-the Calcasieu, Mermentau, and Vermilion-Teche (Figure 1). The three basins sit on the Chicot aquifer, which is the largest freshwater aquifer in Louisiana and hosts the state's most important aquaculture (crawfish) and water-intensive agriculture (i.e., rice) fields. The three basins together overlap the Louisiana Climate Division 7, which exhibited an increasing trend in temperature and precipitation during the period of 1905-2003 [7,8]. Yet this centennial-scale increasing trend in precipitation seems to have changed as streamflow observed at U.S. Geological Survey (USGS) gauges exhibited a decreasing trend for the three rivers in the period of 1990-2009 [14]. Nevertheless, except for streamflow, little is known about the trend of other components of the water cycle, such as evapotranspiration [ET], soil moisture, and water surplus. The studies by Keim et al. [7,8] and Rosen and Xu [14] were largely based on weather and gauge station data and thus were unable to provide a process-based projection of future conditions.

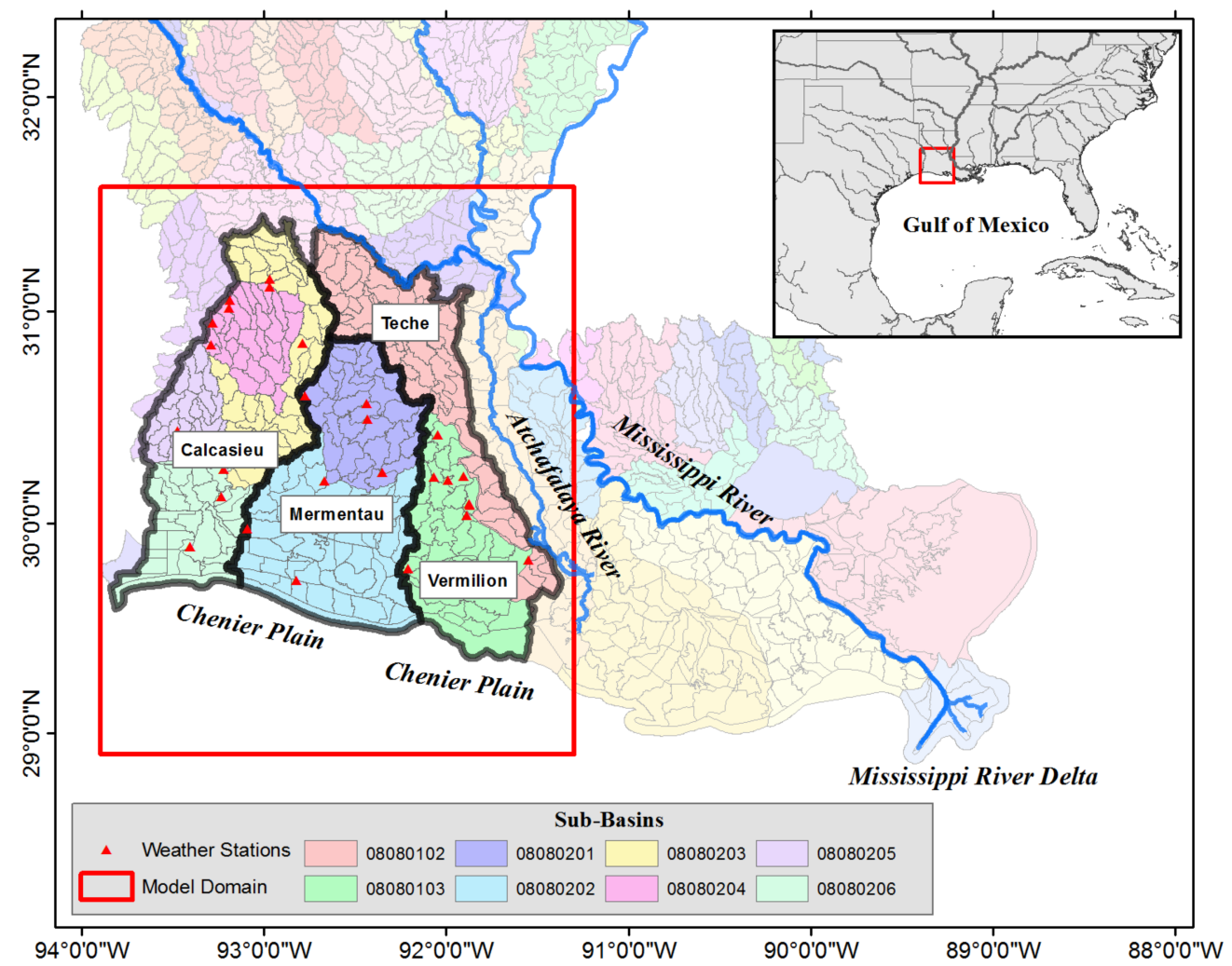

Figure 1. Calcasieu, Mermentau, and Vermilion-Teche basins and their sub-basins (data source: National Hydrography Dataset). Also shown are locations of the National Oceanic and Atmospheric Administration (NOAA) weather stations (red triangles) and WRF-Hydro model domain (red square). 
All three rivers reached a moderate, major, or record flood stage during the 2016 Louisiana Flood, which adds urgency to understanding the coupling between the hydrological regime and climate for the improved assessment of future conditions. In this study, we use North American Land Data Assimilation System Phase 2 (NLDAS-2 hereafter [15]) to drive the newly developed Weather Research and Forecasting Model Hydrological modeling extension package (WRF-Hydro [16,17]). Our objectives are to: (1) evaluate the performance of NLDAS-2-driven WRF-Hydro as a diagnostic tool for regional (Southwest Louisiana) hydroclimatic changes; (2) provide a comprehensive analysis of regional hydroclimatic trends and improve understanding of hydrological variables (e.g., evapotranspiration, soil moisture, water surplus) that have not been examined, and (3) connect regional hydroclimatic change with broad-scale atmospheric drivers in the southeastern United States.

\section{Method}

\subsection{Study Area}

The three adjacent river basins in this study flow in a north-south direction and drain into the northern Gulf of Mexico. To their east is the Atchafalaya River basin and to their west is the Sabine River basin, the latter of which is shared by the states of Texas and Louisiana. The Calcasieu River basin contains four sub-basins (Hydrologic Unit Code [HUC] 08080203 Upper Calcasieu, 08080204 Whiskey Chitto, 08080205 West Fork Calcasieu, and 08080206 Lower Calcasieu) and has an area of $15,423 \mathrm{~km}^{2}$ (calculated using the National Hydrography Dataset [NHD]); the Mermentau River basin contains two sub-basins (HUC 08080201 Mermentau Headwaters and 08080202 Mermentau) and has an area of $13,785 \mathrm{~km}^{2}$; the Vermilion-Teche basin contains two sub-basins (HUC 08080102 Bayou Teche and 08080103 Vermilion) and has an area of $14,696 \mathrm{~km}^{2}$. The study region was covered mainly by cropland (34\%), shrub/savanna/grassland (29\%), and forests (23\%, Table 1). Specifically, the Calcasieu was dominated by forest (41\%), while the Mermentau and Vermilion-Teche basins were dominated by cropland (48\% and $43 \%$, respectively). The small capillary flow and/or small water storage in the clay-dominated soils makes the area particularly susceptible to water surplus during wet periods and drought during dry periods. The general lack of forested land cover in this so-called Cajun Prairie results from this episodic absence of plant available water in topsoil. Accordingly, this area is particularly susceptible to future hydroclimatic extremes since the general circulation model output overwhelmingly suggests that wet periods will become wetter and dry periods will become drier under future scenarios.

Table 1. Land use information for the three basins.

\begin{tabular}{cccccccc}
\hline \multirow{2}{*}{ Basin } & \multirow{2}{*}{ Area $\mathbf{( k m}^{\mathbf{2}} \mathbf{)}$} & \multicolumn{7}{c}{ Land Use (\%) } \\
\cline { 3 - 8 } & & Forest & Shrub/Savanna/Grass & Wetland & Cropland & Urban & Water \\
\hline Calcasieu & 15,423 & 41 & 39 & 5 & 11 & 1 & 3 \\
Mermentau & 13,785 & 8 & 28 & 8 & 48 & $<1$ & 5 \\
Vermilion-Teche & 14,696 & 19 & 18 & 6 & 43 & 1 & 12 \\
Total & 43,904 & 23 & 29 & 6 & 34 & 1 & 6 \\
\hline
\end{tabular}

Source: Moderate Resolution Image Spectroradiometer (MODIS) 2001.

There are also other reasons that this hydroclimatic work is important in this region. The three rivers flow through the Chenier Plain before entering the Gulf of Mexico, where substantial wetland loss is occurring at rate of up to $91 \mathrm{~km}^{2}$ per year (e.g., [18]). Although, compared with their "giant neighbor" - the Mississippi-Atchafalaya River, these three rivers have relatively small water and sediment discharge [14], they become increasingly important in counteracting natural land loss from coastal erosion and marsh subsidence as river diversions are seriously changing the sediment discharge route of the Mississippi-Atchafalaya River [19]. Further, in order to control the Mississippi and Atchafalaya floods and improve water quality, numerous artificial spillways and channels have 
been built in the Vermilion-Teche basin and have dramatically altered its natural streamflow over the past decades [14,20].

\subsection{Model Setup}

WRF-Hydro is a free, open-source, community-based, model-coupling framework designed to link multi-scale process models of the atmosphere and terrestrial hydrology. It is an integrated system that incorporates a land surface model (LSM), grid aggregation/disaggregation, subsurface flow routing, overland flow routing, base flow model, and channel and reservoir routing. It provides the capability to perform coupled and uncoupled multi-physics simulations and predictions of terrestrial water cycle processes on a wide range of spatial and temporal scales. For this study, as our objective was to examine hydrological changes up to decadal scales, we deactivated the direct coupling between the atmospheric (WRF) and hydrological model to ensure a moderate computation load.

We chose the Noah land surface model with multi-parameterization options (Noah-MP, [21]) as WRF-Hydro's LSM, which was driven by the National Center for Atmospheric Research (NCAR) High Resolution Land Data Assimilation System (HRLDAS, [22]). The hourly NLDAS-2 data were applied as lateral boundary conditions for the HRLDAS model and provided information including air temperature, precipitation, wind, short and long wave radiation, humidity, and pressure. The extent of the LSM model domain is shown in Figure 1, which has $249 \times 299$ evenly distributed grid cells with a 1-km horizontal resolution. We used the WRF Pre-processing System (WPS) to prepare the static fields needed by Noah-MP, which included topographic elevation, soil texture (four layers with a total thickness of $2000 \mathrm{~mm}$ ), vegetation fraction, and surface albedo. The land cover information was interpolated using the nearest neighbor method from the Moderate Resolution Imaging Spectroradiometer (MODIS) Land Cover Type product (MCD12Q1, resolution: 500 m, Figure 2), which contained the land cover information collected for the period of 2001-2012. Because our study region's land cover changes during 2001-2012 were minimal, we used the MODIS 2001 product as it was in the middle of our simulation period.

To better represent the physics (e.g., surface flow, subsurface flow, and channel flow) on smaller spatial scales, we generated terrain (surface) routing, subsurface routing, and channel routing grids using the WRF-Hydro GIS Toolbox (Version 2.2, [23]; Digital Elevation Dataset: NHDPlusV2, [24]), which is a Python program embedded within ArcGIS ${ }^{\circledR}$. A regridding factor of 10 was applied and thus yielded $2490 \times 2990$ terrain/subsurface/channel routing grids with a 100-m horizontal resolution (Figure 3). During runtime, selected model state and flux variables were passed to/from the land surface model grid from/to the terrain routing grid via a disaggregation/aggregation scheme. Subsurface lateral flow was calculated prior to the routing of overland flow, while the influence of artificial drainage channels was not incorporated into the model. The method used to calculate the lateral flow of saturated soil moisture was a quasi-three-dimensional flow representation by Wigmosta [25] and Wigmosta and Letternmaier [26], which included the effects of topography, saturated soil depth, and saturated hydraulic conductivity. No effects of soil microrelief were incorporated within the grid cell. The overland flow was calculated when the depth of water on a model grid cell exceeds a specified retention depth. We used the fully unsteady, spatially explicit, diffusive wave formulation of Julien et al. [27] and Ogden et al. [28]. The two-dimensional continuity equation for a flood wave flowing over the land surface is

$$
\frac{\partial h}{\partial t}=\frac{\partial q_{x}}{\partial x}+\frac{\partial q_{y}}{\partial y}=i_{e}
$$

where $h$ is the surface flow depth, $q_{x}$ and $q_{y}$ are the unit discharge in the $\mathrm{x}$ - and $\mathrm{y}$ - directions, respectively; and $i_{e}$ is the infiltration. The momentum equation in the diffusive wave formulation for the $\mathrm{x}$ - or $\mathrm{y}$ dimension is

$$
S_{f x}=S_{o x}-\frac{\partial h}{\partial x} \text { and } S_{f y}=S_{o y}-\frac{\partial h}{\partial y}
$$


where $S_{f x}$ and $S_{f y}$ are the friction slopes in the x-direction and y-direction, respectively, $S_{o x}$ and $S_{o y}$ are the terrain slopes in the $x$-direction and $y$-direction, respectively, and $\frac{\partial h}{\partial x}$ and $\frac{\partial h}{\partial y}$ are the changes in depth of the water surface above the land surface in the x-direction and y-direction, respectively. Channel flow down through the gridded channel network will be performed using an explicit, one-dimensional, variable time-stepping, diffusive wave formulation similar to that used in the overland flow calculation. Baseflow to the channel network was represented using a simple catchment storage-discharge bucket model formulation, which obtained 'drainage' flow from the spatially distributed landscape, neglecting any influence from artificial drainage. We applied an exponential storage-discharge function for estimating the bucket discharge as a function of a conceptual depth of water in the bucket. The details of the physics and equations used for subsurface, overland flow, channel routing, disaggregation/aggregation, and baseflow calculation are listed in Gochis et al. [16].

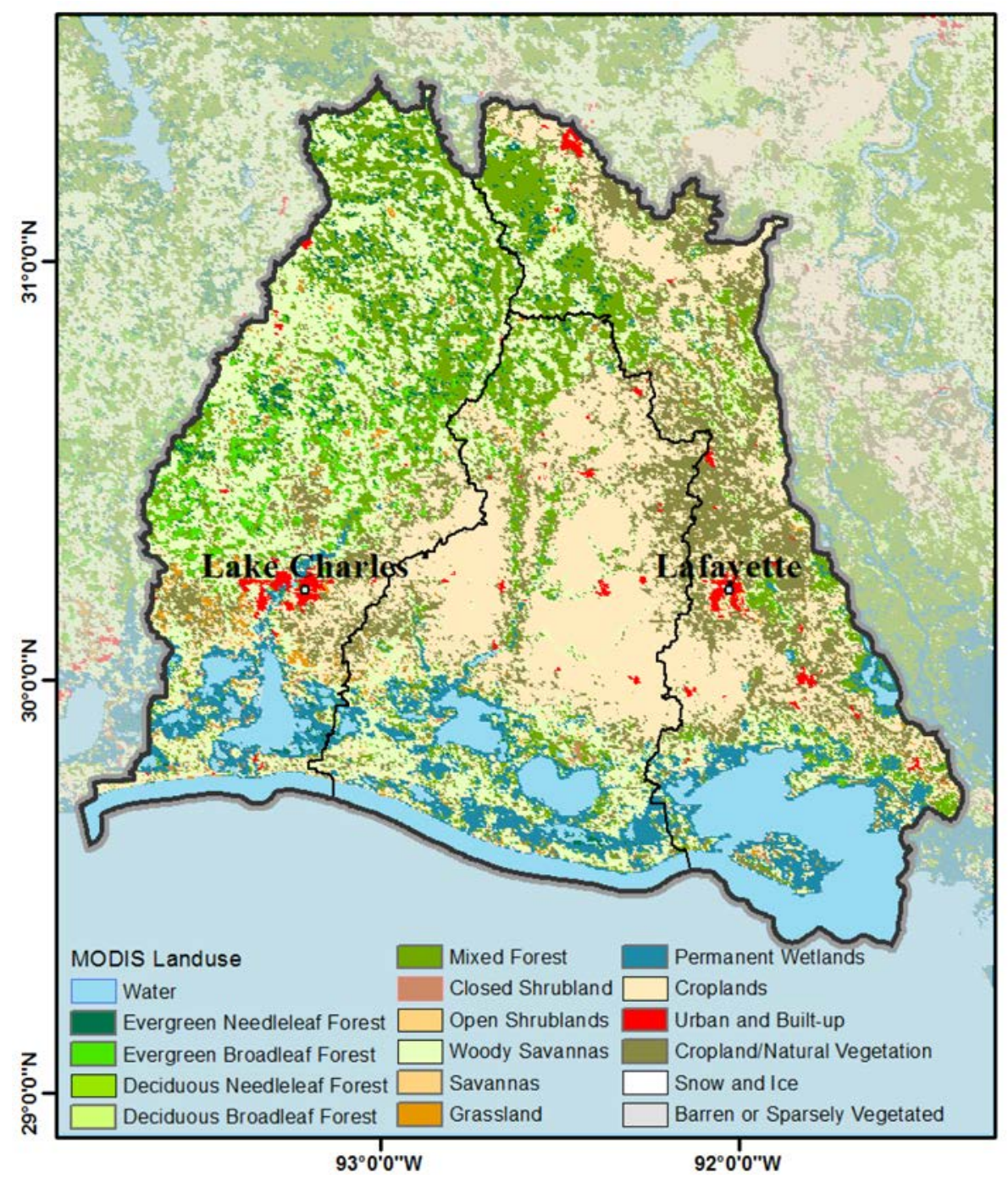

Figure 2. Land cover information of the study region (data source: MODIS 2001).

We used a time step of $3600 \mathrm{sec}$ for LSM and 60/20/20 sec for the surface/subsurface/channel routing model. The model simulation was carried out on supercomputer QB2 of the Louisiana Optical Network Initiative (LONI). A 36-year (1979-2014) simulation required $\sim 300 \mathrm{~h}$ using 8 parallel nodes (20 cores per node). We treated the first six years of simulation as model spin-up to allow the 
hydrological processes to reach a steady state, thus leaving us a 30-year (1985-2014) model solution for the following analyses.

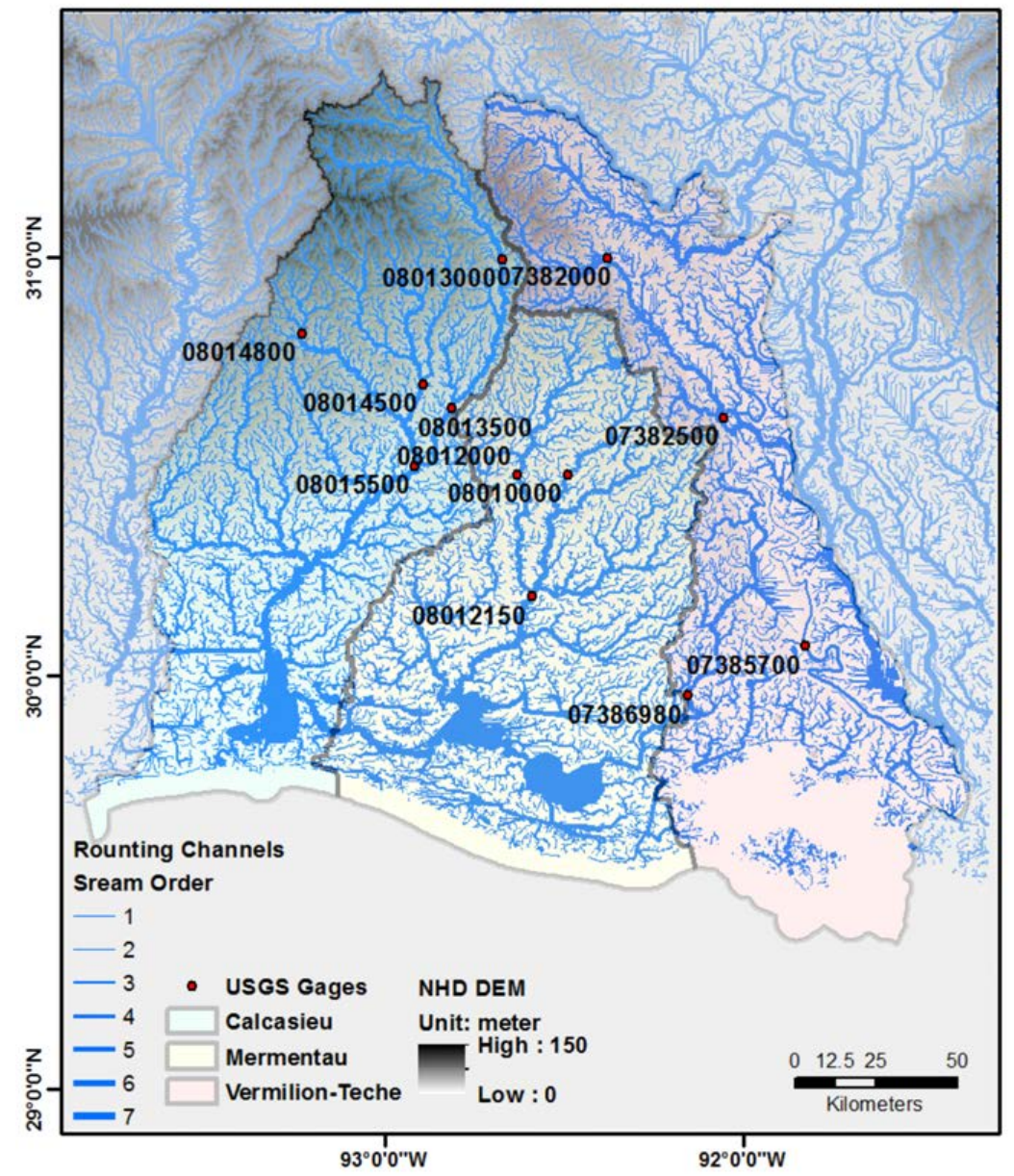

Figure 3. Routing channel grids developed using the WRF-Hydro ArcGIS toolbox. Also shown are digital elevation model (data source: National Hydrography Dataset, V2) and the location of USGS gauges used for streamflow validation.

\subsection{Evaluation of NLDAS-2 Data and WRF-Hydro}

To evaluate NLDAS-2's quality in the study region, we retrieved daily temperature and precipitation data from the Southern Regional Climate Center at LSU (for station locations see Figure 1) as the ground-truth for point measurements of local climate. The weather station data were retrieved programmatically using Application Programming Interfaces (APIs) of the nationwide Applied Climate Information System (ACIS) and hosted by the National Oceanic and Atmospheric Administration (NOAA) Regional Climate Centers of the US (www.rcc-acis.org). The ACIS system is a climate data repository that archives climate data from nearly 26,000 daily reporting weather stations across the country. In this work, climate data were retrieved from 29 weather observation sites in the ACIS that span the hydrological basins that span the three focused rivers. In addition to Pearson's correlation coefficient, we calculated the three quantitative statistics - the Nash-Sutcliffe efficiency (NSE, [29]), percent bias (PBIAS, [30]), and ratio of the root mean square error to the standard deviation of measured data (RSR, [31]) recommended by Moriasi et al. [32]. The details of the statistical techniques are listed in Supplementary Materials (Equations (S1)-(S3)). As suggested by Moriasi et al. [32], model performance can be judged as (1) satisfactory if $0.60<\mathrm{RSR} \leq 0.70,0.50<\mathrm{NSE} \leq 0.65$, and $\pm 15 \% \leq \mathrm{PBIAS}< \pm 25 \%$; 
(2) good if $0.50<\mathrm{RSR} \leq 0.60,0.65<\mathrm{NSE} \leq 0.75$, and $\pm 10 \% \leq$ PBIAS $< \pm 15 \%$; (3) very good if $0.00<$ RSR $\leq 0.50,0.75<$ NSE $\leq 0.100$, and PBIAS $< \pm 10 \%$. The results of statistics are listed in Table 2.

Table 2. Comparison between weather station and North American Land Data Assimilation System (NLDAS-2) data over basins.

\begin{tabular}{cccccccccccc}
\hline \multirow{2}{*}{ Basins } & \multirow{2}{*}{$\begin{array}{c}\text { Number of } \\
\text { Stations }\end{array}$} & \multicolumn{3}{c}{ Temperature (Monthly Mean, Unit: ${ }^{\circ}$ C) } & \multicolumn{4}{c}{ Precipitation (Monthly, Unit: mm) } \\
\cline { 3 - 11 } & & Station & NDLAS-2 & RSR & NSE & PBIAS & Station & NDLAS & RSR & NSE & PBIAS \\
\hline Calcasieu & 12 & 19.79 & 20.01 & 0.11 & 0.99 & $-1 \%$ & 128.86 & 131.97 & 0.47 & 0.78 & $-2 \%$ \\
Mermentau & 8 & 20.08 & 20.50 & 0.18 & 0.98 & $-2 \%$ & 131.78 & 139.15 & 0.54 & 0.71 & $-5 \%$ \\
Vermilion-Teche & 9 & 20.10 & 20.33 & 0.16 & 0.97 & $-1 \%$ & 132.58 & 133.56 & 0.54 & 0.71 & $-1 \%$ \\
Entire Region & 29 & 19.99 & 20.27 & 0.12 & 0.98 & $-1 \%$ & 131.07 & 134.77 & 0.44 & 0.81 & $-3 \%$ \\
\hline
\end{tabular}

RSR: RMSE-observations standard deviation ratio; NSE: Nash-Sutcliffe efficiency; PBIAS: percent bias.

Satellite-derived ET rate can be an effective source to evaluate the performance of a LSM (e.g., [33]). The ET calculated by the Noah-MP LSM consists of direct soil evaporation, canopy transpiration, and evaporation from canopy interception [34]. We compared model-simulated ET against the MOD16 dataset [35]. Although MOD16 provides monthly ET covering the period of 2001-2014, there are large spatial gaps in the dataset due to the presence of moisture and clouds, specifically for the study region with a humid subtropical climate. Thus, in this study we compared the monthly climatology averaged through 2001-2014 with that computed by LSM.

To evaluate the hydrologic model's performance, we retrieved daily streamflow from 12 USGS gauge stations (for station locations see Figure 3). At each station, there were at least five years of continuous measurements overlapping with our analysis period (data details see Table 3). To evaluate the model's "goodness-of-fit", we calculated the Pearson's correlation coefficient, as well as NSE, RSR, and PBIAS (see Equations (S1)-(S3) in Supplementary Materials). To assure that model-simulated streamflow reflects the same trend as that of gauge data, we performed a trend and change-point test on both observed and simulated streamflow time series using the method described below.

\subsection{Trend and Wavelet Analysis}

For monthly data, we performed a seasonal Mann-Kendall test $[36,37]$ to minimize data seasonality. For annual data, in addition to the standard Mann-Kendall test, we calculated Sen's Slope [38] for the linear rate of change and the corresponding intercept. We also performed Pettitt's test [39] to detect a potential change-point and identify nonlinear trends in a time series. As the climate and hydrological variables of the three basins in general exhibited a similar trend over the period of 1985-2014, we grouped them together and performed trend and change-point analysis on a regional scale. The trend analysis, Sen's Slope, and Pettitt's test were carried out using the 'trend' package in R by Pohlert [40] and equations for the trend test are listed in Supplementary Materials (Equations (S4)-(S15)).

We aggregated the conditions over the three basins and performed continuous wavelet transform (CWT) on the monthly anomaly of ET, soil moisture, water surplus, and streamflow to detect their frequency. In addition, to assess the coupling between climate and hydrology, we performed wavelet coherence (WTC) analysis between the monthly anomaly of climate (temperature/precipitation) and selected model-simulated variables (ET, soil moisture, water surplus, and streamflow). The wavelet analysis was carried out using the MATLAB package presented in Grinsted et al. [41], which computes the wavelet power spectra using the Morlet wavelet. This method has widespread application in hydrology due to its frequency resolution and ability to detect both time-dependent amplitude and phase for different frequencies in the time series [42]. Details of the equations used for CWT and WTC analysis are listed in Supplementary Materials, Equations (S16)-(S19). It is important to note that coherence between two wavelet spectra does not indicate correlation at high power, but that similar oscillations are occurring in each series at the frequency of interest. 
Table 3. Information of USGS gauge stations and model-data comparison.

\begin{tabular}{|c|c|c|c|c|c|c|c|c|c|c|c|}
\hline Basin & Station id & Lon & Lat & Covered Period ${ }^{*}$ & \# of Month & Monthly Mean Runoff $\left(\mathrm{m}^{3} \cdot \mathrm{s}^{-1}\right)$ & $\mathbf{r}$ & r (for Anomaly) & RSR & NSE & PBIAS \\
\hline \multirow{5}{*}{ Calcasieu } & 08013000 & -92.673 & 30.996 & $01 / 85-12 / 14$ & 360 & 21.40 & 0.91 & 0.89 & 0.41 & 0.83 & $3 \%$ \\
\hline & 08013500 & -92.814 & 30.641 & $01 / 85-12 / 14$ & 348 & 28.63 & 0.95 & 0.94 & 0.33 & 0.89 & $-12 \%$ \\
\hline & 08014500 & -92.893 & 30.699 & $01 / 85-12 / 14$ & 360 & 20.82 & 0.90 & 0.88 & 0.53 & 0.72 & $-10 \%$ \\
\hline & 08014800 & -93.231 & 30.819 & 09/07-12/14 & 87 & 3.06 & 0.85 & 0.76 & 0.76 & 0.43 & $-39 \%$ \\
\hline & 08015500 & -92.915 & 30.503 & $01 / 85-12 / 14$ & 360 & 68.42 & 0.93 & 0.92 & 0.38 & 0.86 & $-8 \%$ \\
\hline \multirow{3}{*}{ Mermentau } & 08010000 & -92.491 & 30.483 & $01 / 85-12 / 14$ & 360 & 7.85 & 0.83 & 0.81 & 0.60 & 0.65 & $24 \%$ \\
\hline & 08012000 & -92.632 & 30.481 & $01 / 85-12 / 14$ & 360 & 22.66 & 0.89 & 0.87 & 0.47 & 0.78 & $11 \%$ \\
\hline & 08012150 & -92.591 & 30.190 & $10 / 89-12 / 14$ & 292 & 62.28 & 0.85 & 0.83 & 0.56 & 0.68 & $15 \%$ \\
\hline \multirow{4}{*}{ Vermilion-Teche } & 07382000 & -92.380 & 31.000 & $01 / 85-12 / 14$ & 336 & 11.13 & 0.90 & 0.89 & 0.51 & 0.74 & $5 \%$ \\
\hline & $07382500^{* *}$ & -92.056 & 30.618 & $01 / 85-11 / 14$ & 240 & 27.30 & 0.93 & 0.88 & 0.74 & 0.45 & $56 \%$ \\
\hline & 07385700 ** & -91.829 & 30.071 & $01 / 85-12 / 14$ & 360 & 13.12 & 0.88 & 0.80 & 1.98 & -2.92 & $91 \%$ \\
\hline & 07386980 ** & -92.156 & 29.952 & $01 / 85-12 / 14$ & 339 & 33.55 & 0.72 & 0.63 & 0.96 & 0.07 & $42 \%$ \\
\hline
\end{tabular}

* there are missing data periods at certain stations; ${ }^{* *}$ stations with extensive artificial alternation. 


\section{Results}

\subsection{Model-Data Comparison}

In Figure 4 we compare monthly-averaged NLDAS-2 precipitation and temperature (spatially averaged over the three basins) against weather station records averaged over the three basins. The comparison of time series shows adequate agreement between NLDAS-2 and weather station data. The statistics of comparison between NLDAS-2 and station data are listed in Table 2. For all three basins, NLDAS-2 shows very good agreement with station-based observations for temperature. The RSR ranges between 0.11 and 0.18 , NSE ranges between 0.97 and 0.99 , and PBIAS are less than $-2 \%$. For precipitation, agreement of the regional mean is "Good" to "Very Good" for RSR (0.47 0.54), "Very Good" for NSE (0.71 0.81), and "Very Good" for PBIAS (-1\% -5\%). Nevertheless, we notice that NLDAS-2 misses some temperature and precipitation extremes (e.g., high temperature in 2004 summer, high precipitation rate in 1989 and 2003, Figure 4) and ascribe such discrepancies to the relatively poor spatial resolution $(4 \mathrm{~km})$ of the NLDAS-2 data.
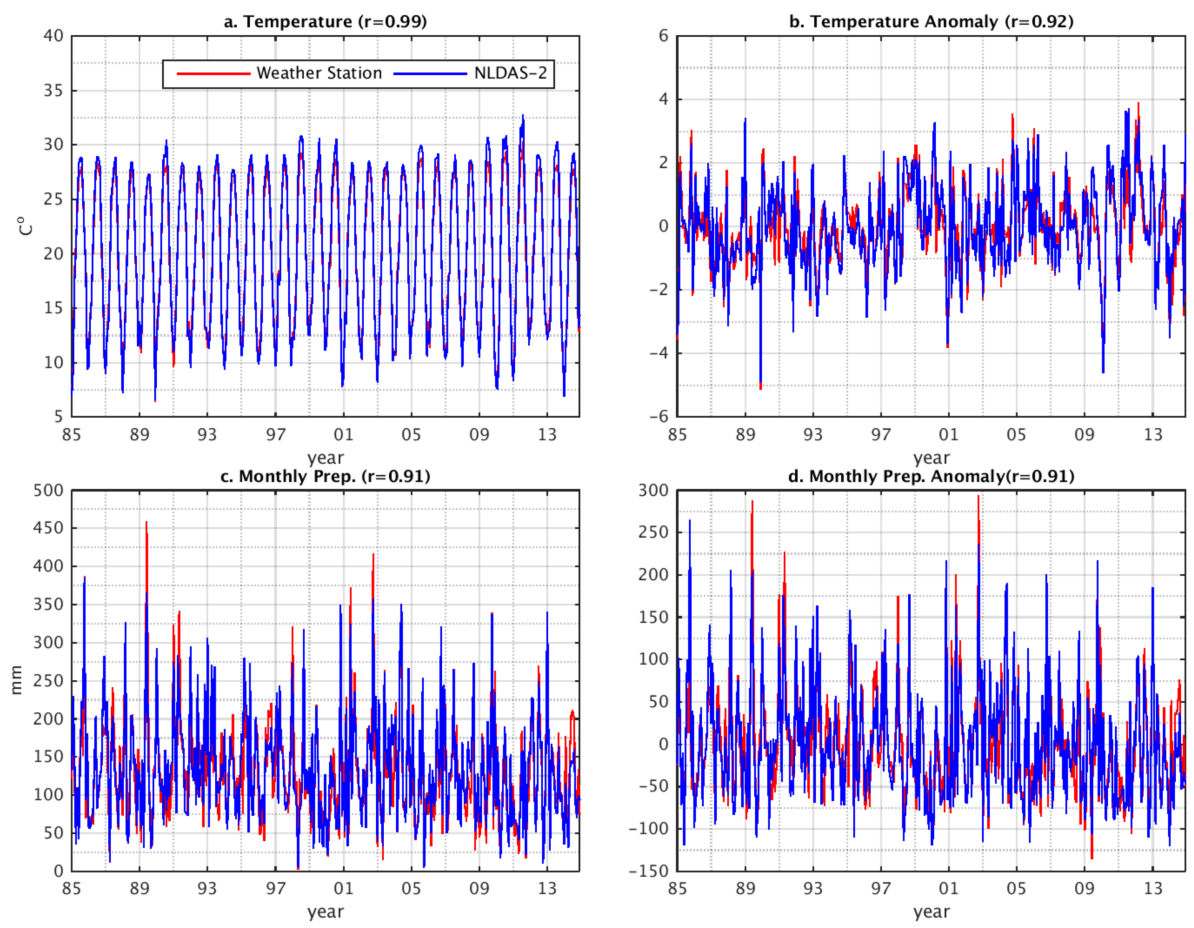

Figure 4. Comparison of the monthly temperature (a) and precipitation (c) time series and their anomaly (b,d) from 1985 to 2014 from NLDAS-2 (blue) against weather station records (red).

A comparison between satellite-derived and model-simulated multi-year ET climatology averaged for each basin is shown in Figure 5. Our model is able to reproduce the magnitude and seasonal variations of satellite-derived ET in all three basins. The model-data correlation coefficient is 0.98 for the Calcasieu, 0.99 for the Mermentau, and 0.98 for the Vermilion-Teche basin.

The hydrological model is capable of reproducing the monthly variations of streamflow at most of the 12 gauging stations (e.g., see Figure 6 for a comparison at three stations-one for each basin). Averaged model-data correlation coefficient at the 12 stations is 0.88 for monthly mean streamflow (up to 360 data points at each station) and 0.84 for monthly anomaly (Table 3 ). We notice that the model missed some extreme high- or low-flow conditions and ascribe this discrepancy to the quality of NLDAS-2's precipitation data. For RSR, NSE, and PBIAS, our model performs better in the two basins with less human activity (Calcasieu and Mermentau) than in the Vermilion-Teche basin, where there were more artificial waterways and diversions, which were unaccounted for in the model. 
For the Calcasieu, the hydrological model's performance is "Good" to "Very Good" at four of the five gauges for RSR, NSE, and PBIAS. The station with relatively poor performance (\#08014800) is located on a small branch with limited streamflow. For the Mermentau, the model's performance is "Good" to "Very Good" for RSR at all three stations, "Good" for NSE at all three stations, and "Good" to "Very Good" for PBIAS at two of the three stations. For the Vermilion-Teche basin, the model's performance is "Very Good" for RSR, NSE, and PBIAS at the station in the upstream with less human disturbance (\#07382000). As no artificial channel modification or water pumping information is incorporated in the model, simulated streamflow cannot fully capture changes at the three stations in the Vermilion sub-basin. Nevertheless, here we focus on natural processes' impact on the hydrological regime and thus our model results of the Vermilion-Teche basin should reflect an "undisturbed" or "intact" mode (i.e., assuming there were no artificial waterways). In addition, the trend and change-point test on monthly and annual streamflow time series described below confirmed that the model-simulated streamflow exhibits a same trend with that based on gauge records (Table 4).
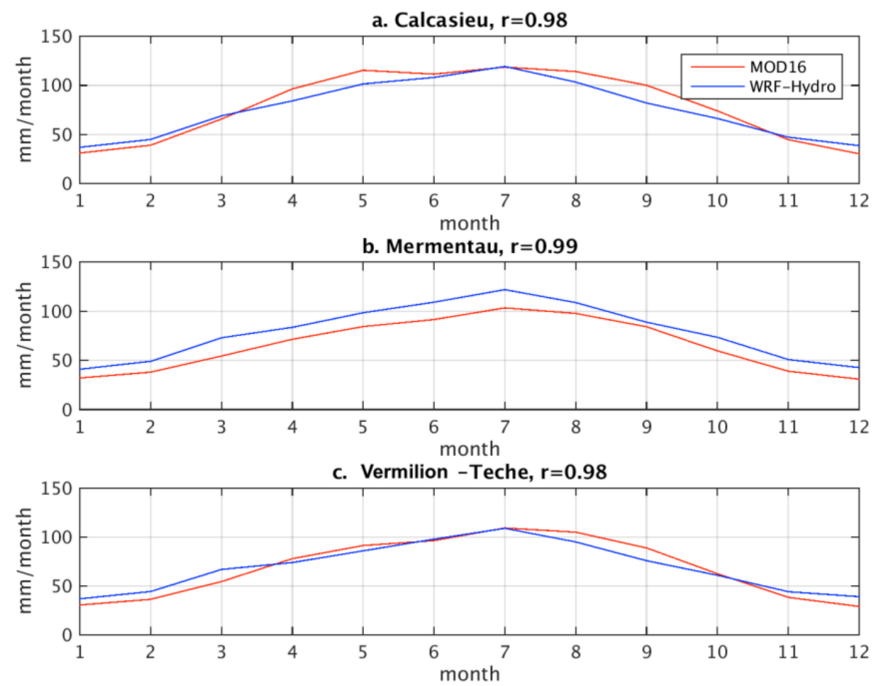

Figure 5. A comparison of monthly climatology of the evapotranspiration simulated by the Land Surface Model (blue) against satellite product (MOD16; red) for (a) Calcasieu, (b) Mermentau, and (c) Vermilion-Teche basins.

\subsection{Temporal Variation}

The monthly mean and multi-decadal climatological and hydrological variables are shown in Figures 7 and 8, respectively. Ground temperature exhibits minimal difference among the three basins. Over a year, the highest temperature is found in August and the lowest temperature in January. Relatively low temperatures are found in the Calcasieu basin, which is covered mainly by forest instead of cropland (Figures 7a and 8a; for land cover see Figure 2). The study region has a mean annual precipitation of $1626 \mathrm{~mm} \cdot$ year $^{-1}$. Among the three basins, the Mermentau has the highest precipitation rate $\left(1679 \mathrm{~mm} \cdot\right.$ year $^{-1}$, Figures $7 \mathrm{~b}$ and $\left.8 \mathrm{~b}\right)$, followed by the Vermilion-Teche $\left(1612 \mathrm{~mm} \cdot\right.$ year $\left.^{-1}\right)$, and Calcasieu $\left(1592 \mathrm{~mm} \cdot\right.$ year $\left.^{-1}\right)$. Precipitation in the three basins exhibits a similar temporal pattern, with the highest rates in January, June, and July and the lowest rate in April. Although ET exhibits a similar temporal pattern with that of temperature, it peaks in July while the temperature peaks in August. Among the three basins, the Mermentau has the highest annual ET rate $\left(1029 \mathrm{~mm} \cdot\right.$ year $^{-1}$, Figure $\left.8 \mathrm{c}\right)$, followed by the Vermilion-Teche $\left(990 \mathrm{~mm} \cdot \mathrm{year}^{-1}\right)$, and Calcasieu $\left(953 \mathrm{~mm} \cdot\right.$ year $\left.^{-1}\right)$. Over a year, in all three basins, soil moisture is highest in February and lowest in August (Figure 8d). With impacts from the Atchafalaya River to the east, soil moisture content is highest in the Vermilion-Teche basin (multi-decadal mean, $0.351 \mathrm{~m}^{3} \cdot \mathrm{m}^{-3}$ ), followed by the Mermentau $\left(0.342 \mathrm{~m}^{3} \cdot \mathrm{m}^{-3}\right)$ and Calcasieu basins $\left(0.331 \mathrm{~m}^{3} \cdot \mathrm{m}^{-3}\right)$. 
Table 4. Statistics of Trend Analysis.

\begin{tabular}{|c|c|c|c|c|c|c|c|c|c|}
\hline \multirow{2}{*}{ River } & \multirow{2}{*}{ Variables } & \multicolumn{2}{|c|}{ Seasonal Mann-Kendall ( $n=360$ months) } & \multicolumn{2}{|c|}{ Mann-Kendall $(n=30$ year) } & \multicolumn{2}{|c|}{ Sen's Slope $(n=30$ year) } & \multicolumn{2}{|c|}{ Pettitt's Change-Point ( $n=30$ year) } \\
\hline & & S Score* & $p$-Value & S Score * & $p$-Value & Slope & Intercept & Change Point (Year) & $p$-Value \\
\hline \multirow{7}{*}{ Calcasieu } & Ground Temp. & 499 & 0.010 & 123 & 0.029 & 0.025 & 19.469 & 1997 & 0.037 \\
\hline & Precipitation & -434 & 0.025 & -59 & 0.301 & -7.344 & 1735.008 & 1997 & 0.762 \\
\hline & ET & 628 & 0.001 & 103 & 0.069 & 1.824 & 913.596 & 2000 & 0.149 \\
\hline & Soil Moisture & -880 & $<0.001$ & -79 & 0.164 & $<-0.001$ & 0.342 & 2008 & 0.299 \\
\hline & Surplus & -412 & 0.033 & -109 & 0.054 & -11.028 & 828.732 & 2004 & 0.195 \\
\hline & Streamflow (obs.) & -1178 & $<0.001$ & -139 & 0.014 & -1.481 & 87.918 & 2004 & 0.042 \\
\hline & Streamflow (model) & -674 & $<0.001$ & -85 & 0.134 & -1.101 & 87.141 & 2004 & 0.276 \\
\hline \multirow{7}{*}{ Mermentau } & Ground Temp. & 467 & 0.016 & 128 & 0.023 & 0.024 & 19.927 & 1997 & 0.037 \\
\hline & Precipitation & -389 & 0.047 & -85 & 0.134 & -10.572 & 1795.056 & 2004 & 0.300 \\
\hline & ET & 392 & 0.043 & 89 & 0.116 & 1.884 & 987.084 & 2000 & 0.111 \\
\hline & Soil Moisture & -788 & $<0.001$ & -89 & 0.116 & $<-0.001$ & 0.351 & 2004 & 0.232 \\
\hline & Surplus & -460 & 0.018 & -113 & 0.046 & -12.300 & 836.304 & 2004 & 0.135 \\
\hline & Streamflow (obs) & -498 & 0.010 & -107 & 0.059 & -0.295 & 26.050 & 2004 & 0.090 \\
\hline & Streamflow (model) & -800 & $<0.001$ & -103 & 0.169 & -0.340 & 25.503 & 2004 & 0.179 \\
\hline \multirow{7}{*}{ Vermilion-Tech } & Ground Temp. & 665 & $<0.001$ & 154 & 0.006 & 0.030 & 19.685 & 1997 & 0.009 \\
\hline & Precipitation & -554 & 0.004 & -143 & 0.113 & -17.604 & 1796.424 & 1995 & 0.056 \\
\hline & ET & 212 & 0.275 & 41 & 0.475 & 0.600 & 972.78 & 2000 & 0.829 \\
\hline & Soil Moisture & -1053 & $<0.001$ & -131 & 0.020 & $<-0.001$ & 0.363 & 1997 & 0.062 \\
\hline & Surplus & -580 & 0.003 & -159 & 0.005 & -17.676 & 802.248 & 1995 & 0.045 \\
\hline & Streamflow (obs) & -208 & 0.284 & -35 & 0.544 & -0.044 & 14.124 & 1998 & 0.740 \\
\hline & Streamflow (model) & -604 & 0.002 & -79 & 0.164 & -0.167 & 16.396 & 2004 & 0.214 \\
\hline \multirow{7}{*}{ 3-basins } & Ground Temp. & 567 & 0.003 & 135 & 0.017 & 0.027 & 19.669 & 1997 & 0.023 \\
\hline & Precipitation & -464 & 0.017 & -113 & 0.046 & -13.08 & 1870.968 & 2004 & 0.254 \\
\hline & ET & 414 & 0.032 & 93 & 0.101 & 1.788 & 951.96 & 2000 & 0.148 \\
\hline & Soil Moisture & -919 & $<0.001$ & -93 & 0.101 & $<-0.001$ & 0.353 & 2004 & 0.233 \\
\hline & Surplus & -476 & 0.014 & -147 & 0.009 & -14.124 & 886.848 & 2004 & 0.047 \\
\hline & Streamflow ** (obs) & -912 & $<0.001$ & -123 & 0.030 & -1.943 & 126.570 & 2004 & 0.053 \\
\hline & Streamflow (model) & -712 & $<0.001$ & -91 & 0.108 & -1.425 & 115.498 & 2004 & 0.254 \\
\hline
\end{tabular}

* streamflow for Calcasieu, Mermentau, and Vermilion-Teche is based on observed and model results at stations 08015500, 08012000, 07385000, respectively (continuous data covering 1985-2014); ** the streamflow is a combination of the three USGS gauges. 

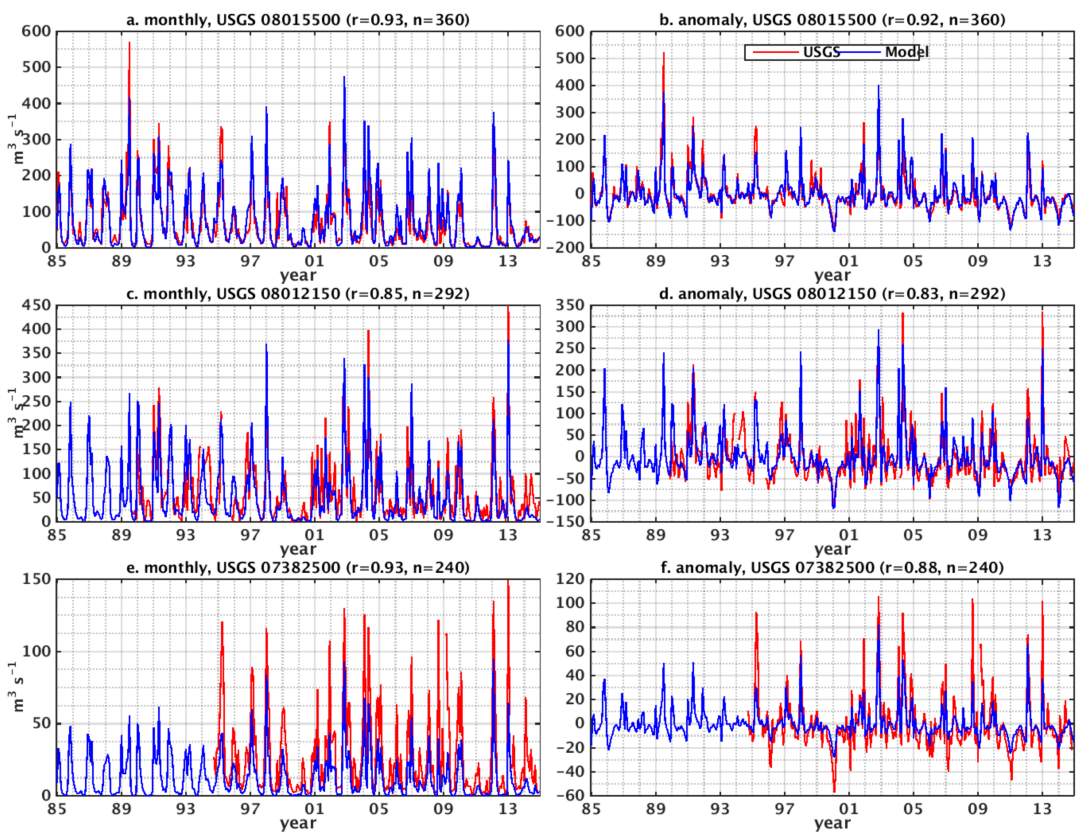

Figure 6. Monthly time series and anomaly of model simulated (blue) and observed (red) streamflow at (a,b) Calcasieu River near Kinder, LA (USGS 08015500), (c,d) Mermentau River at Mermentau, LA (USGS 08012150), and (e,f), Bayou Courtableau of the Vermilion-Teche basin at Washington, LA (USGS 07382500) from 1985 to 2014.
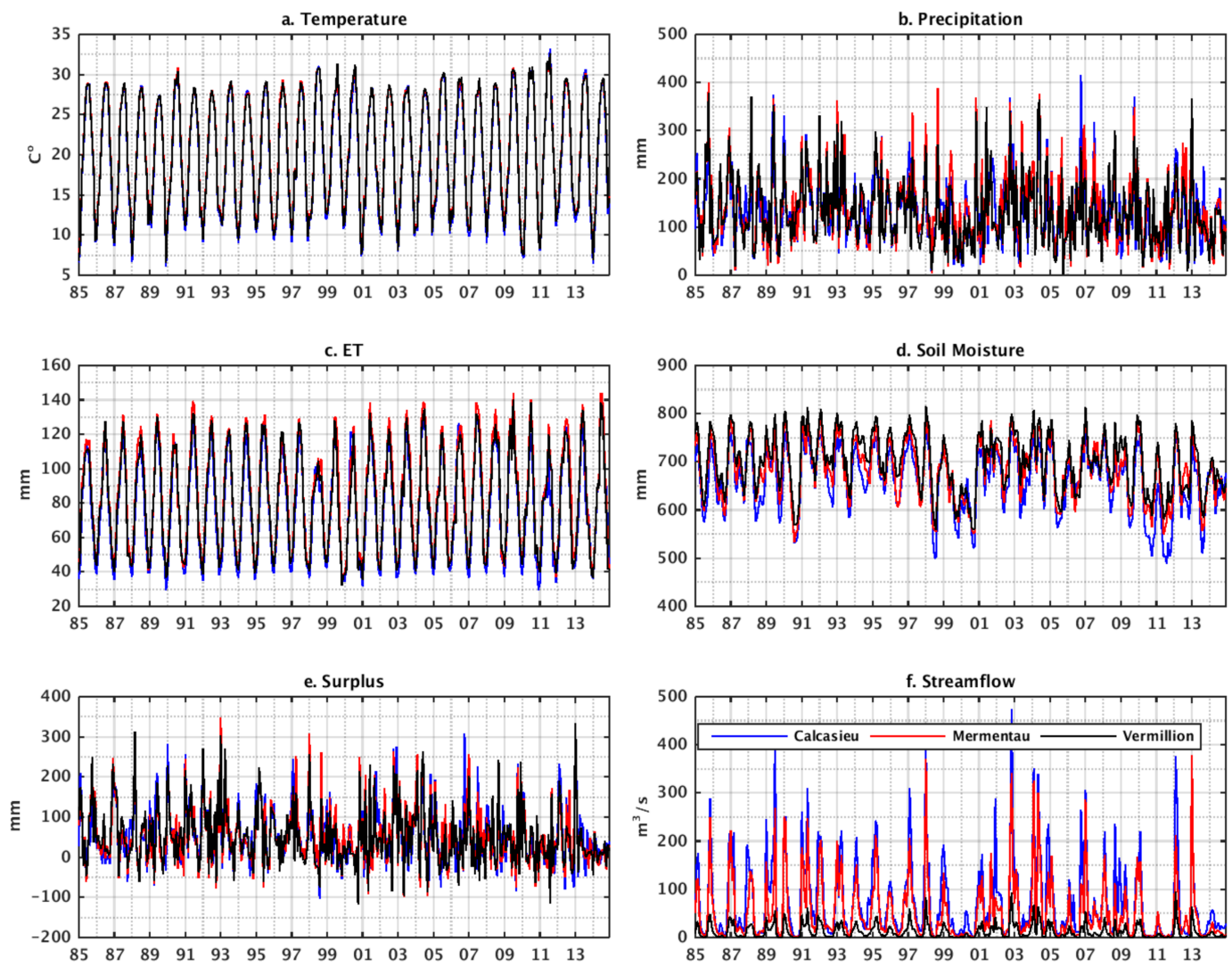

Figure 7. Monthly (a) temperature, and (b) precipitation from NLDAS-2, and model simulated monthly (c) evapotranspiration, (d) soil moisture, (e) water surplus, and (f) streamflow for the Calcasieu (blue), Mermentau (red), and Vermilion (black). 

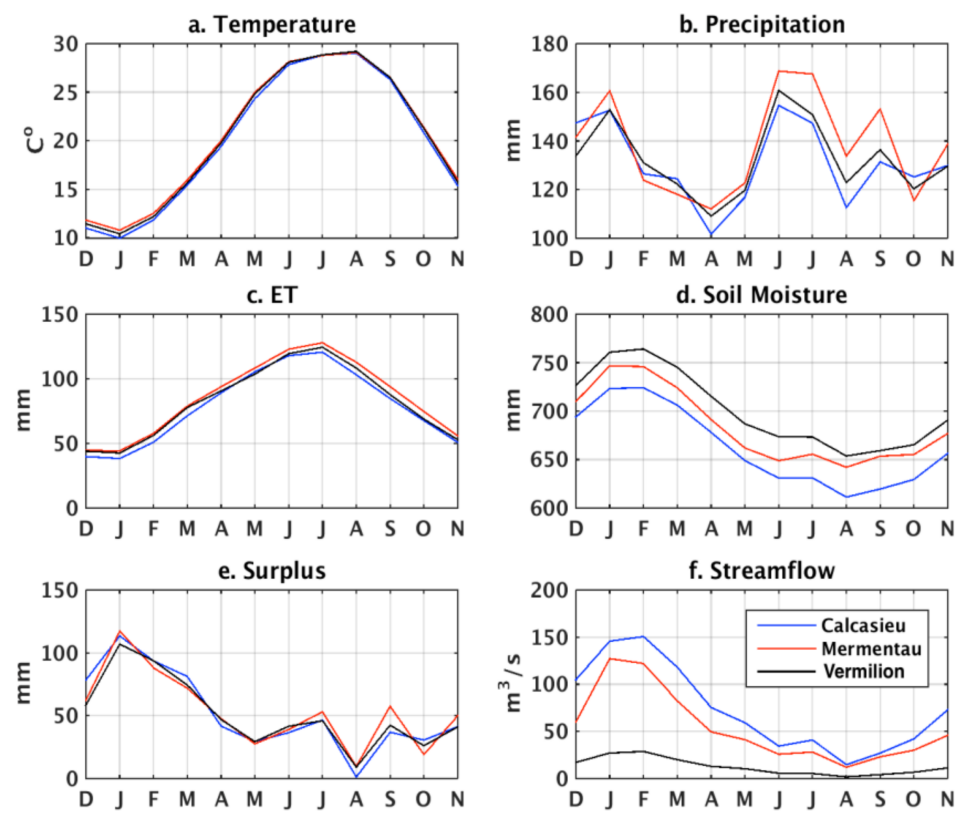

Figure 8. Monthly (a) temperature, and (b) precipitation from NLDAS-2, and model simulated monthly (c) evapotranspiration, (d) soil moisture, (e) water surplus, and (f) streamflow for the Calcasieu (blue), Mermentau (red), and Vermilion (black) basins.

We calculated the monthly Thornthwaite water balance following Thornthwaite [43] and Mather [44] as follows:

$$
P=E T+C_{S}+S
$$

where $P$ is precipitation $(\mathrm{mm})$; ET is Evapotranspiration $(\mathrm{mm})$, which is the sum of canopy evaporation, soil evaporation, and transpiration; $C_{S}$ is the change in soil water content $(\mathrm{mm})$; and $S$ is water surplus (mm). The study region is located in the subtropical zone; thus, snowmelt is not considered in the water balance calculation. Because the lag between the generation of surplus water from precipitation and the resultant streamflow is very short [7], effectively the water surplus is synonymous with runoff. Nevertheless, we keep the term "surplus" from this point forward to differentiate it from the streamflow simulated by the hydrological model. Despite the differences in precipitation and soil moisture, water surplus in the three basins exhibits a similar magnitude and temporal pattern (Figures $7 \mathrm{e}$ and $8 \mathrm{e}$ ). The three basins generally gain water from October to the next May and lose water from June through September. Water surplus peaks in January ( 100 to $120 \mathrm{~mm}$ ) when maximum precipitation occurs and reaches its minimum in August $(\sim 0$ to $10 \mathrm{~mm})$ when temperature peaks and the high ET has largely reduced the soil moisture in June and July. While rice irrigation is important in the basin, its overall impact on the hydroclimatology of the basins is relatively minor because of the wet climate, the concentration of the crop near the mouths of the basins, and the harvesting of the crop before the hydroclimatologically driest late summer/early fall.

Model-simulated streamflow at the last USGS gauge before entering the ocean is shown in Figures 7f and 8f (USGS 08015500 for Calcasieu, 08012150 for Mermentau, and 07386980 for Vermilion). River streamflow follows a similar temporal pattern to soil moisture (i.e., peaks in February and minimizes in August). Here the magnitude of the streamflow does not necessarily reflect the amount of the water discharged to the ocean, as these stations only represent part of the watershed.

\subsection{Trend Analysis}

Time series of the regional mean annual NDLAS and model-simulated variables are shown in Figure 9 together with Sen's Slope. Although their statistical significance is different, monthly and annual time series exhibit identical trends for a given variable in the three basins. Over the past 
30 years, temperature and ET show an increasing trend, while precipitation, soil moisture, water surplus, and streamflow show a decreasing trend (Table 4 and Figure 9). Specifically, for monthly time series, the trend for temperature, precipitation, soil moisture, water surplus, and observed and simulated streamflow are statistically significant with $90 \%$ confidence $(p$-value $<0.10)$. For annual time series, the trend for temperature, precipitation, water surplus, and observed streamflow are significant with a $90 \%$ confidence. The Sen's Slope estimator confirms the increasing trend for temperature and ET and the decreasing trend for precipitation, soil moisture, water surplus, and streamflow, both in the three basins calculated separately and on a regional scale. Change-points are detected around 1997 for temperature, 2000 for ET, and 2004 for precipitation, soil moisture, water surplus, and streamflow. On a regional scale, trends of temperature, water surplus, and observed streamflow are statistically significant. For Vermilion-Teche, the change-point in streamflow was identified in 1998, largely because of the impoundment of a major river diversion project in 1997 [14].
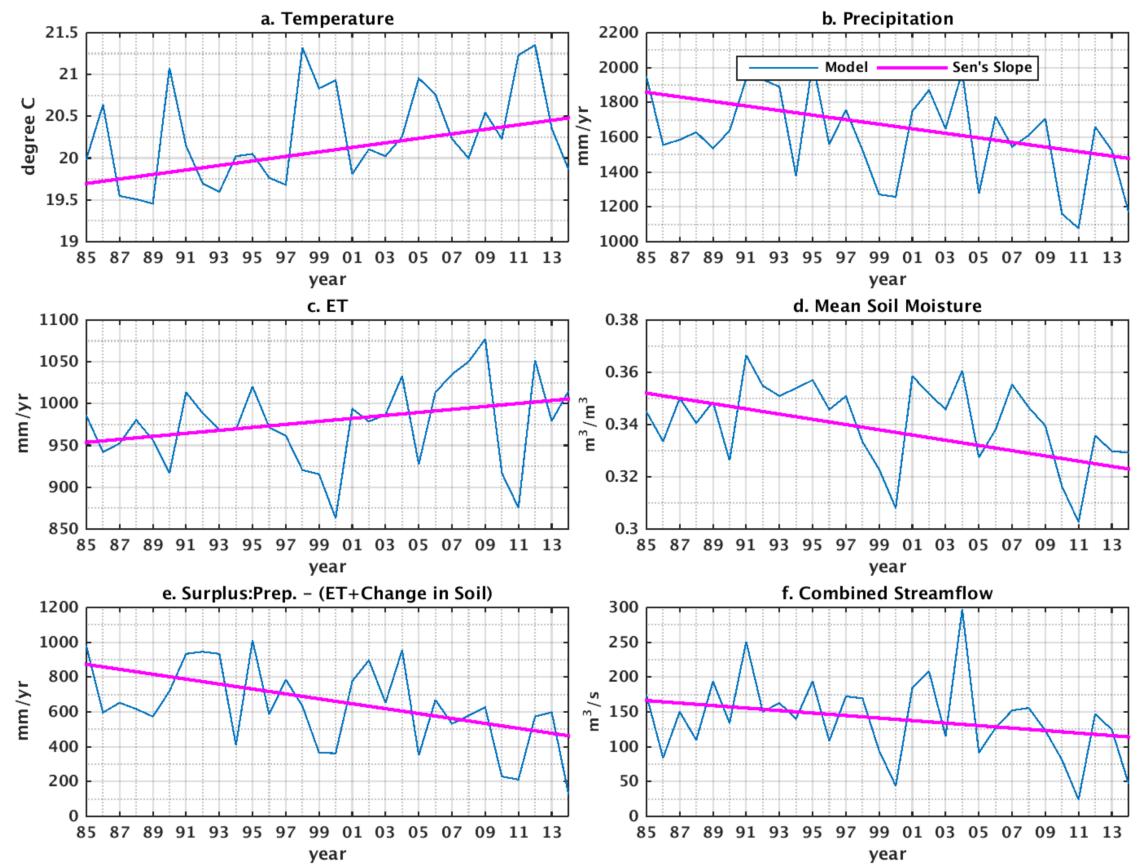

Figure 9. Annual mean time series of NLDAS-2 (a) temperature and (b) precipitation, and model simulated (c) evapotranspiration, (d) soil moisture, (e) water surplus, (f) combined streamflow averaged through the three basins for year 1985-2014. Also shown in each figure is the Sen's Slope (magenta).

\subsection{Wavelet Analysis}

The monthly anomaly of ET, soil moisture, and streamflow exhibit high power around the 2- to 4-year and 4- to 8-year band starting from late 1990s (Figure 10a,d,j). While the high power around the 4- to 8-year band is connected with temperature anomalies (Figure 10b,e,k), strong in-phase coherency appears on the precipitation-ET, precipitation-soil moisture, and precipitation-streamflow WTC after the late 1990s (Figure 10c,f,l). Compared with streamflow, the water surplus anomaly exhibits relatively low power at the 2- to 4-year and 4- to 8-year bands (Figure 10g). While water surplus' coherency with temperature anomaly is also weak on the 4- to 8-year period (Figure 10h), the precipitation-water surplus WTC exhibits high power throughout the temporal and periodicity domain, indicating that changes of water surplus are dominated by that of precipitation (Figure 10i). In sum, high or relatively high powers are identified around the 2- to 4-year and 4- to 8-year band on CWT. While the anomaly of water surplus is always connected with precipitation, the coherency between precipitation and ET, precipitation and soil moisture, and precipitation and streamflow are elevated substantially since late 1990s. 

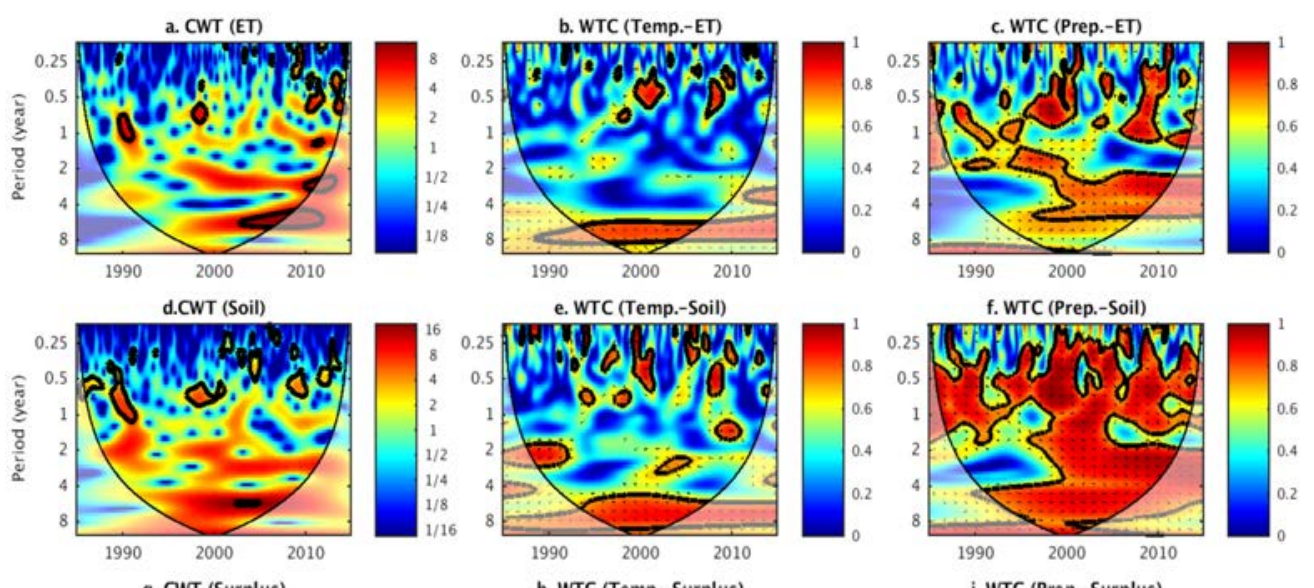

f. WTC (Prep.-Soil)
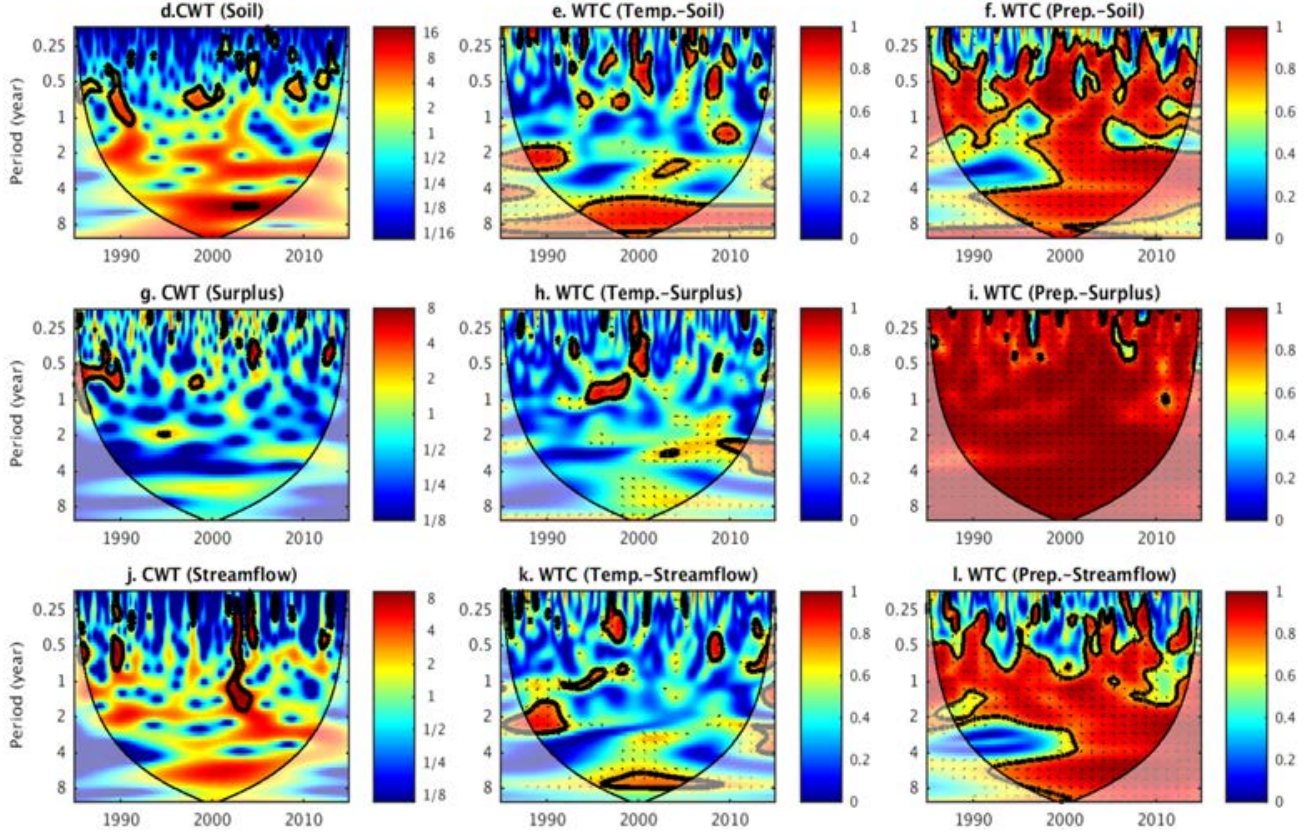

Figure 10. Continuous wavelet transform (CWT) of monthly anomaly of model-simulated (a) evapotranspiration, (d) soil moisture, (g) water surplus, and (j) streamflow and squared wavelet coherence (WTC) between temperature anomaly and the anomaly of model-simulated (b) evapotranspiration, (e) soil moisture, (h) water surplus, and (k) streamflow; between precipitation anomaly and anomaly model-simulated (c) evapotranspiration, (f) soil moisture, (i) water surplus, and (1) streamflow. The horizontal axis is the 30 years of records beginning January 1985 . Thicker lines bounding areas of red indicate significant coherence at the $95 \%$ level against red noise. Arrows indicate the phase difference between the wavelet spectra (right arrows indicate series are in phase, left arrows indicate series are completely out of phase). Thin solid lines indicate the cone of influence outside of which paler colors indicate the influence of edge effects and must be viewed with caution.

\section{Discussion}

In this section we discuss regional climate's connection with large-scale climate, followed by a comparison of the climate and hydroloclimatology before and after the change-point (2004).

To connect regional climate with large-scale climate dynamics, we further performed WTC analyses between temperature/precipitation anomaly and NAO/AMO/ENSO(NINO3.4)/PDO indexes. We found that while regional temperature anomalies, specifically during summer months, are strongly coupled with the AMO index, precipitation is associated with the NINO3.4 index (Figure 11). The AMO has been dominated by its most recent warm phase since 1995 (Figure 11a), when ENSO entered its cold phase (Figure 11c). Two years later in 1997, a significant change-point is detected in the regional temperature time series (Table 4). Sanchez-Rubio et al., [12] discovered that a significantly lower river flow (Pascagoula River in the adjacent State of Mississippi in their case) could be expected during the coupling between the AMO warm and ENSO cold phases. Thus, for the three basins in this study, the decreasing water surplus and streamflow could start as early as 1997. However, the connection between regional and large-scale climate is not persistent after 1997. The high power in the AMO-temperature WTC appears in the 4- to 8-year band since summer 2002, and in the 
1- to 2-year and 2- to 4-year bands since 2009 (Figure 11b). For the ENSO-precipitation WTC, although a high power is persistent around the 4- to 8-year band, a "new" high power emerges in the 2-year band after 2004, when change-points are eventually identified in precipitation, soil moisture, water surplus, and streamflow time series. In other words, significant decreases in water surplus could be expected when both AMO (warm phase)-temperature and ENSO (cold phase)-precipitation coupling become salient.

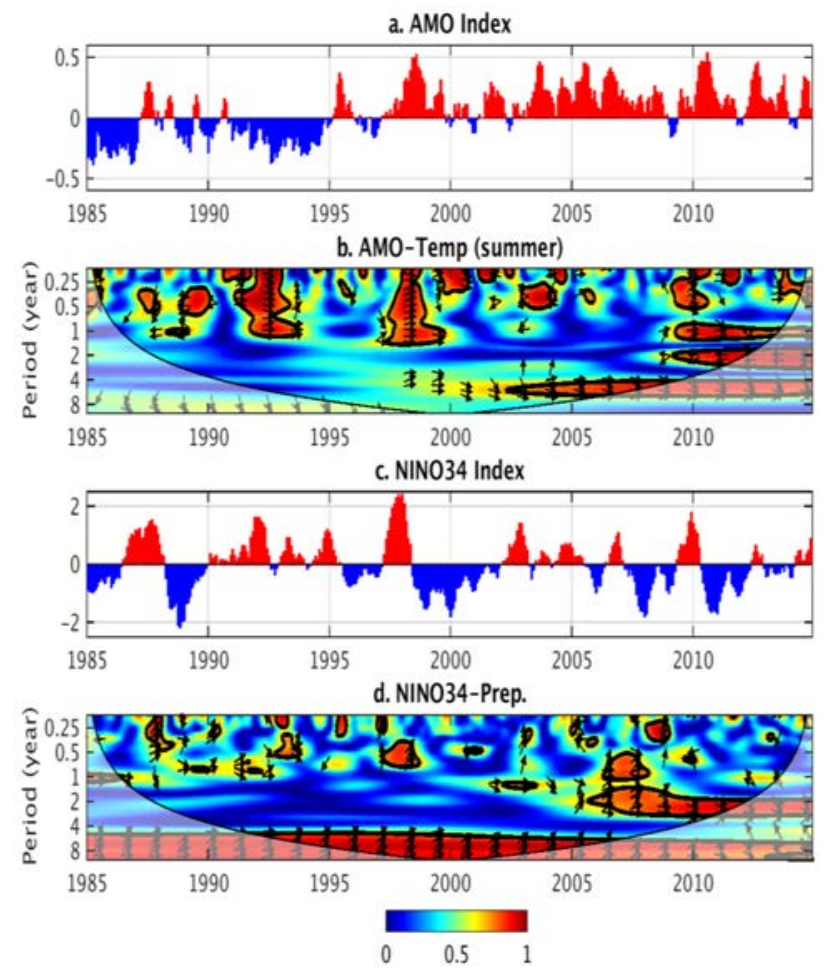

Figure 11. Time series (1985-2014) of monthly (a) AMO and (c) NINO3.4 indexes and squared wavelet coherence between (b) AMO index and summer temperature anomaly, and (d) NINO34 index and monthly precipitation anomaly.

Given the above discussion of a possible change-point around 2004, the local hydrological response to the changing climate could be better illustrated by comparing the conditions before and after 2004. Figure 12 shows the monthly climatological and hydrological variables grouped by the period of 1985-2004 and 2005-2014 (three basins combined). A warmer summer and drier winter characterize the local climate during the period of 2005-2014. The annual mean temperature increased slightly $\left(20.1\right.$ to $20.6^{\circ} \mathrm{C}$ ) while monthly precipitation experienced decrease from 140 to $120 \mathrm{~mm}$. The higher temperature and reduced precipitation resulted in a slight increase of ET (from $80 \mathrm{~mm}$ to $83 \mathrm{~mm}$ ) and a slight decrease in soil moisture (from 690 to $664 \mathrm{~mm}$ ) for the top $2000 \mathrm{~mm}$, or 0.345 to $0.332 \mathrm{~m}^{3} \cdot \mathrm{m}^{-3}$ ). The most substantial decrease was found in water surplus, which showed a drop from 60 to $38 \mathrm{~mm}$. The combined streamflow at three USGS stations also experienced a reduction from 143 to $98 \mathrm{~m}^{3} \cdot \mathrm{s}^{-1}$. Intriguingly, there was a shift in precipitation distribution from a bimodal peak in winter and early summer to a bimodal peak in July and September. As a result, the starting point of net loss in water budget advanced from April to March. While the impact of such shifts on groundwater recharge is still unknown, the warm and dry conditions during the growing season could adversely affect agriculture. An earlier net loss in water budget could also have negative impacts in wetland environments, such as by encouraging an affliction called brown marsh that is related to protracted drought, increased salinity levels, low input of freshwater, and excessive heat and evaporation $[8,45]$. 

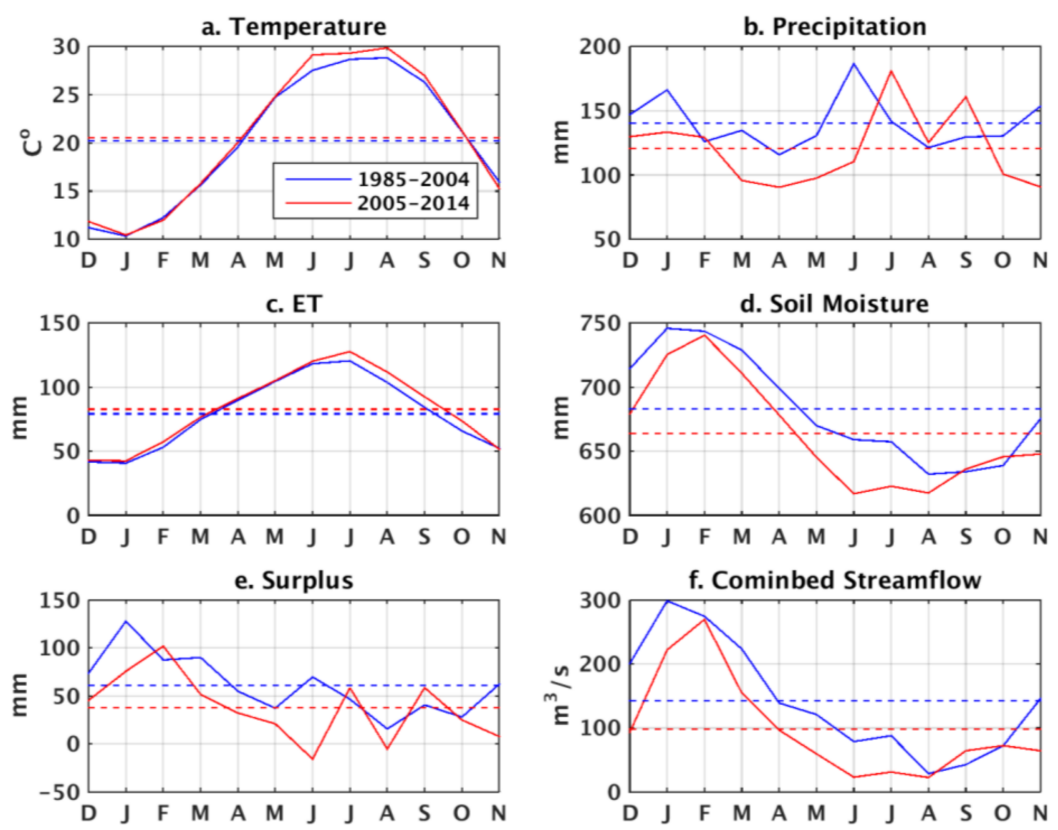

Figure 12. Comparison of monthly climatology for the period of 1985-2004 (blue) against that of the period of 2005-2014 (red) for (a) temperature, (b) precipitation, (c) evapotranspiration, (d) soil moisture, (e) water surplus, and (f) combined streamflow at USGS 08015500, 08012150, and 07386980. The dashed line is the annual mean condition.

Caution should be exercised in the interpretation of results. This study focuses on conditions over the past three decades only. Our study confirms the decreasing trend in streamflow documented by Rosen and Xu [14] for the period of 1990-2009. Nevertheless, the decreasing trend in precipitation and water surplus found here contrast with results of Keim et al., [8] for the period from 1889 to 1991. Clearly, weather patterns have changed across the region in recent decades and are now trending more toward warmer and drier conditions, with more frequent droughts (e.g., in 2000, 2006, and 2011). This is certainly consistent with the streamflow and modeled surplus reductions found here. The possibility of decreased water supply in this presently water-rich area could have repercussions for agriculture, coastal sediment accretion, freshwater fisheries, and other important human and natural processes. In addition to longterm trend, more extreme climate events are also likely to be introduced to this region in the near future. A good example is the historical Louisiana flood in August 2016, during which a stationary low pressure system brought $500 \mathrm{~mm}$ precipitation to this region within $72 \mathrm{~h}$. A statistical analysis of the outputs from the six global coupled models indicated that the regional probability of 3-day extreme precipitation increased by more than a factor of 1.4 due to climate change introduced by human activities [46]. The impacts from such an intensive precipitation on regional hydroclimatic conditions warrants further study.

\section{Conclusions}

This study adapted WRF-Hydro to three river basins in southwestern Louisiana (Calcasieu, Mermentau, and Vermilion), which exhibit contradicting hydroclimatic trends over centennial and decadal scales. Driven by the NLDAS-2 dataset, a 35-year model hindcast was performed covering the period of 1979-2014. An evaluation of model performance against available observations indicated that our model is capable of reproducing annual cycles of satellite-derived ET as well as the magnitude and multi-decadal trend of streamflow at USGS gauges. While the model's performance is generally "Good" to "Very Good" for RSR, NSE, and PBIAS in most of the stations within the Calcasieu and Mermentau basins, further model development is required to capture the influence from artificial drainage and irrigation activities within the three basins. 
Trend and wavelet analyses of NLDAS-2 and model-simulated time series indicate a slightly increasing ET, a decreasing soil moisture, and a substantially reduced water surplus, coinciding with the warmer and drier climate in the period of 1985-2014. A possible change-point is identified around 2004, after which the water surplus decreased by $36.4 \%$. Changes in regional climatic conditions are closely correlated with broad-scale climate dynamics, and a significant decrease in water surplus could be expected when a warm phase AMO is coupled with a cold phase ENSO.

Supplementary Materials: The following are available online at http:/ /www.mdpi.com/2073-4441/10/5/596/s1, Equations S1 to S19.

Author Contributions: Z.G.X. designed and performed the experiments and analyzed the data; D.G., W.Y., K.S., and A.D. provided support to model setup and experiment design; Z.G.X., B.K., R.R., Z.Z., and Q.G. discussed the results and wrote the paper; D.S. provided the weather station data and related analysis.

Funding: This project was funded by The Water Institute of the Gulf under project "Project Louisiana Rivers' Sediment Flux to the Coastal Ocean using a Coupled Atmospheric-Hydrological Model" (award number RCEGR260003-01-00). This project was paid for (in part) with federal funding from the Department of the Treasury through the Louisiana Coastal Protection and Restoration Authority's Center of Excellence Research Grants Program under the Resources and Ecosystems Sustainability, Tourist Opportunities, and Revived Economies of the Gulf Coast States Act of 2012 (RESTORE Act). The statements, findings, conclusions, and recommendations are those of the author(s) and do not necessarily reflect the views of the Department of the Treasury, CPRA or The Water Institute of the Gulf. Additional supports from National Oceanic and Atmospheric Administration (award number NA16NOS4780204), National Science Foundation (award number CCF-1539567), Fund of China National Programme on Global Change and Air-Sea Interaction (Grant Nos. GASI-GEOGE-03 and GASI-04-01-02), and the National Natural Science Foundation of China (Grant Nos. 41476047 and 41106045) is also appreciated.

Acknowledgments: We thank the Louisiana Optical Network Initiative (LONI) for providing high performance computing time and support. The weather station data were provided by the Southern Regional Climate Center at LSU. The MODIS MCD12Q1 data product was retrieved from the online Data Pool, courtesy of the NASA Land Processes Distributed Active Archive Center (LP DAAC), USGS/Earth Resources Observation and Science (EROS) Center, Sioux Falls, South Dakota, https://lpdaac.usgs.gov/data_access/data_pool. The NLDAS-2 data used in this study were acquired as part of the mission of NASA's Earth Science Division and archived and distributed by the Goddard Earth Sciences (GES) Data and Information Services Center (DISC). Personal communication with Xitian Cai at Lawrence Berkeley National Laboratory and Chris Swarzenski at USGS Lower-Mississippi Gulf Water Science Center largely improved the quality of the manuscript.

Conflicts of Interest: The authors declare no conflict of interest.

\section{References}

1. Vörösmarty, C.J.; Green, P.; Salisbury, J.; Lammers, R.B. Global water resources: Vulnerability from climate change and population growth. Science 2000, 289, 284-288. [CrossRef] [PubMed]

2. McGranahan, G.; Balk, D.; Anderson, B. The rising tide: Assessing the risks of climate change and human settlements in low elevation coastal zones. Environ. Urban. 2007, 19, 17-37. [CrossRef]

3. Nicholls, R.J.; Cazenave, A. Sea-level rise and its impact on coastal zones. Science 2010, 328, 1517-1520. [CrossRef] [PubMed]

4. Ferguson, G.; Gleeson, T. Vulnerability of coastal aquifers to groundwater use and climate change. Nat. Clim. Chang. 2012, 2, 342-345. [CrossRef]

5. Knutson, T.R.; McBride, J.L.; Chan, J.; Emanuel, K.; Holland, G.; Landsea, C.; Held, I.; Kossin, J.P.; Srivastava, A.K.; Sugi, M. Tropical cyclones and climate change. Nat. Geosci. 2010, 3, 157-163. [CrossRef]

6. Powell, E.J.; Keim, B.D. Trends in daily temperature and precipitation extremes for the Southeastern United States: 1948-2012. J. Clim. 2015, 28, 1592-1612. [CrossRef]

7. Keim, B.D.; Faiers, G.E.; Muller, R.A.; Grymes, J.M.; Rohli, R.V. Long-term trends of precipitation and runoff in Louisiana, USA. Int. J. Climatol. 1995, 15, 531-541. [CrossRef]

8. Keim, B.D.; Fontenot, R.; Tebaldi, C.; Shankman, D. Hydroclimatology of the US Gulf Coast under global climate change scenarios. Phys. Geogr. 2011, 32, 561-582. [CrossRef]

9. Enfield, D.B.; Mestas-Nuñez, A.M.; Trimble, P.J. The Atlantic Multidecadal Oscillation and its relation to rainfall and river flows in the continental US. Geophys. Res. Lett. 2001, 28, 2077-2080. [CrossRef]

10. McCabe, G.J.; Palecki, M.A.; Betancourt, J.L. Pacific and Atlantic Ocean influences on multidecadal drought frequency in the United States. Proc. Natl. Acad. Sci. USA 2004, 101, 4136-4141. [CrossRef] [PubMed] 
11. Knight, J.R.; Folland, C.K.; Scaife, A.A. Climate impacts of the Atlantic multidecadal oscillation. Geophys. Res. Lett. 2006, 33, L17706. [CrossRef]

12. Sanchez-Rubio, G.; Perry, H.M.; Biesiot, P.M.; Johnson, D.R.; Lipcius, R.N. Oceanic-atmospheric modes of variability and their influence on riverine input to coastal Louisiana and Mississippi. J. Hydrol. 2011, 396, 72-81. [CrossRef]

13. Nohara, D.; Kitoh, A.; Hosaka, M.; Oki, T. Impact of climate change on river discharge projected by multimodel ensemble. J. Hydrometeorol. 2006, 7, 1076-1089. [CrossRef]

14. Rosen, T.; Xu, Y. Riverine sediment inflow to Louisiana Chenier Plain in the Northern Gulf of Mexico. Estuar. Coast. Shelf Sci. 2011, 95, 279-288. [CrossRef]

15. Xia, Y.; Mitchell, K.; Ek, M.; Sheffield, J.; Cosgrove, B.; Wood, E.; Luo, L.; Alonge, C.; Wei, H.; Meng, J.; et al. Continental-scale water and energy flux analysis and validation for the North American Land Data Assimilation System project phase 2 (NLDAS-2): 1. Intercomparison and application of model products. J. Geophy. Res. Atmos. 2012, 117. [CrossRef]

16. Gochis, D.J.; Yu, W.; Yates, D.N. The WRF-Hydro Model Technical Description and User's Guide, Version 3.0. NCAR Technical Document. 2015, p. 120. Available online: http://www.ral.ucar.edu/projects/wrf_hydro/ (accessed on 1 May 2018).

17. Gochis, D.; Schumacher, R.; Friedrich, K.; Doesken, N.; Kelsch, M.; Sun, J.; Ikeda, K.; Lindsey, D.; Wood, A.; Dolan, B.; et al. The great Colorado flood of September 2013. Bull. Am. Meteorol. Soc. 2015, 96, 1461-1487. [CrossRef]

18. Turner, R.E. Wetland loss in the northern Gulf of Mexico: Multiple working hypotheses. Estuaries 1997, 20, 1-13. [CrossRef]

19. Coastal Protection and Restoration Authority of Louisiana. Fiscal Year 2011 Annual Plan: Integrated Ecosystem Restoration and Hurricane Protection in Coastal Louisiana; Coastal Protection and Restoration Authority of Louisiana: Baton Rouge, LA, USA, 2010.

20. Baker, N.T. Hydrologic Features and Processes of the Vermilion River, Louisiana. In Water-Resources Investigations Report 88-4019; United States Geological Survey: Reston, VA, USA, 1988.

21. Niu, G.-Y.; Yang, Z.L.; Mitchell, K.E.; Chen, F.; Ek, M.B.; Barlage, M.; Kumar, A.; Manning, K.; Niyogi, D.; Rosero, E.; et al. The community Noah land surface model with multiparameterization options (Noah-MP): 1. Model description and evaluation with local-scale measurements. J. Geophys. Res. Atmos. 2011, 116. [CrossRef]

22. Chen, F.; Manning, K.W.; LeMone, M.A.; Trier, S.B.; Alfieri, J.G.; Roberts, R.; Tewari, M.; Niyogi, D.; Horst, T.W.; Oncley, S.P.; et al. Description and evaluation of the characteristics of the NCAR high-resolution land data assimilation system. J. Appl. Meteorol. Climatol. 2007, 46, 694-713. [CrossRef]

23. Sampson, K.; Gochis, D.J. WRF Hydro GIS Pre-Processing Tools; Version 2.2; National Center for Atmospheric Research, Research Application Laboratory: Boulder, CO, USA, 2015.

24. McKay, L.; Bondelid, T.; Dewald, T.; Johnston, J.; Moore, R.; Rea, A. NHDPlus Version 2: User Guide; National Operational Hydrologic Remote Sensing Center: Washington, DC, USA, 2012.

25. Wigmosta, M.S.; Vail, L.W.; Lettenmaier, D.P. A distributed hydrology-vegetation model for complex terrain. Water Resour. Res. 1994, 30, 1665-1679. [CrossRef]

26. Wigmosta, M.S.; Lettenmaier, D.P. A comparison of simplified methods for routing topographically driven subsurface flow. Water Resour. Res. 1999, 35, 255-264. [CrossRef]

27. Julien, P.Y.; Saghafian, B.; Ogden, F.L. Raster-based hydrologic modeling of spatially-varied surface runoff. J. Am. Water Resour. Assoc. 1995, 31, 523-536. [CrossRef]

28. Ogden, F.; Sharif, H.O.; Senarath, S.U.S.; Smith, J.A.; Baeck, M.L.; Richardson, J.R. Hydrologic analysis of the Fort Collins, Colorado, flash flood of 1997. J. Hydrol. 2000, 228, 82-100. [CrossRef]

29. Nash, J.E.; Sutcliffe, J.V. River flow forecasting through conceptual models part I-A discussion of principles. J. Hydrol. 1970, 10, 282-290. [CrossRef]

30. Gupta, H.V.; Sorooshian, S.; Yapo, P.O. Status of automatic calibration for hydrologic models: Comparison with multilevel expert calibration. J. Hydrol. Eng. 1999, 4, 135-143. [CrossRef]

31. Singh, J.; Knapp, H.V.; Arnold, J.; Demissie, M. Hydrological modeling of the Iroquois River watershed using HSPF and SWAT. J. Am. Water Resour. Assoc. 2005, 41, 343-360. [CrossRef] 
32. Moriasi, D.N.; Arnold, J.G.; Van Liew, M.W.; Bingner, R.L.; Harmel, R.D.; Veith, T.L. Model evaluation guidelines for systematic quantification of accuracy in watershed simulations. Trans. ASABE 2007, 50, 885-900. [CrossRef]

33. Cai, X.; Yang, Z.-L.; David, C.H.; Niu, G.-Y.; Rodell, M. Hydrological evaluation of the Noah-MP land surface model for the Mississippi River Basin. J. Geophys. Res. Atmos. 2014, 119, 23-38. [CrossRef]

34. Chen, F.; Mitchell, K.; Schaake, J.; Xue, Y.; Pan, H.; Koren, V.; Duan, Q.Y.; Ek, M.; Betts, A. Modeling of land surface evaporation by four schemes and comparison with FIFE observations. J. Geophys. Res. Atmos. 1996, 101, 7251-7268. [CrossRef]

35. Mu, Q.; Zhao, M.; Running, S.W. Improvements to a MODIS global terrestrial evapotranspiration algorithm. Remote Sens. Environ. 2011, 115, 1781-1800. [CrossRef]

36. Hipel, K.W.; McLeod, A.I. Time Series Modelling of Water Resources and Environmental Systems; Elsevier: London, UK, 1994.

37. Libiseller, C.; Grimvall, A. Performance of partial Mann-Kendall tests for trend detection in the presence of covariates. Environmetrics 2002, 13, 71-84. [CrossRef]

38. Sen, P.K. Estimates of the regression coefficient based on Kendall's tau. J. Am. Stat. Assoc. 1968, 63, 1379-1389. [CrossRef]

39. Pettitt, A. A non-parametric approach to the change-point problem. Appl. Stat. 1979, 28, 126-135. [CrossRef]

40. Pohlert, T. Non-Parametric Trend Tests and Change-Point Detection, CC BY-ND 4.0. 2016.

41. Grinsted, A.; Moore, J.C.; Jevrejeva, S. Application of the cross wavelet transform and wavelet coherence to geophysical time series. Nonlinear Process. Geophys. 2004, 11, 561-566. [CrossRef]

42. Carey, S.K.; Tetzlaff, D.; Buttle, J.; Laudon, H.; McDonnell, J.; McGuire, K.; Seibert, J.; Soulsby, C.; Shanley, J. Use of color maps and wavelet coherence to discern seasonal and interannual climate influences on streamflow variability in northern catchments. Water Resour. Res. 2013, 49, 6194-6207. [CrossRef]

43. Thornthwaite, C.W. An approach toward a rational classification of climate. Geogr. Rev. 1948, 38, 55-94. [CrossRef]

44. Mather, J.R. The Climatic Water Budget in Environmental Analysis; Free Press: Glencoe, IL, USA, 1978.

45. Subudhi, P.K.; Parami, N.; Materne, M.; Harrison, S. Genetic diversity in smooth cordgrass from brown marsh areas of Louisiana. J. Aquat. Plant Manag. 2008, 46, 60-67.

46. Van der Wiel, K.; Kapnick, S.B.; Jan van Oldenborgh, G.; Whan, K.; Philip, S.; Vecchi, G.A.; Singh, R.K.; Arrighi, J.; Cullen, H. Rapid attribution of the August 2016 flood-inducing extreme precipitation in south Louisiana to climate change. Hydrol. Earth Syst. Sci. 2017, 21, 897. [CrossRef] 